\title{
Cell suspension culture as a means to produce polyphenols from date palm (Phoenix dactylifera L.)
}

\section{Cultura de suspensão celular como meio de produção de polifenóis a partir de tamareira (Phoenix dactylifera L.)}

\author{
Poornananda Madhava Naik, Jameel Mohammed Al-Khayri \\ ${ }^{1}$ King Faisal University, College of Agriculture and Food Sciences, Department of Agricultural Biotechnology, Al-Hassa, Saudi Arabia \\ *Corresponding author: jkhayri@kfu.edu.sa; jmkhayri@yahoo.com \\ Received in July 13, 2018 and approved in September 14, 2018
}

\begin{abstract}
Date palm accumulates a wide range of secondary metabolites high in nutritional and therapeutic value. In the present study, date palm (Phoenix dactylifera L., cv. Shaishi) shoot-tip-induced callus was used to establish cell suspension cultures in Murashige and Skoog (MS) liquid medium containing $1.5 \mathrm{mg} \mathrm{L}^{-1}$ 2-isopentenyladenine (2iP) and $10 \mathrm{mg} \mathrm{L}^{-1}$ naphthaleneacetic acid (NAA). To study the growth kinetics, cultures were maintained for 12 weeks during which weekly measurements were carried out to determine the biomass accumulation based on packed cell volume (\%), fresh weight and dry weight (g). In addition, weekly determination of polyphenols (catechin, caffeic acid, kaempferol, and apigenin) was carried out using high performance liquid chromatography (HPLC). The 11-week-old culture was found highest in the production of biomass $\left(62.9 \mathrm{~g} \mathrm{~L}^{-1}\right.$ fresh weight and $7.6 \mathrm{~g} \mathrm{~L}^{-1} \mathrm{dry}$ weight) and polyphenols (catechin-155.9 $\mu \mathrm{g} \mathrm{L^{-1 }}$, caffeic acid-

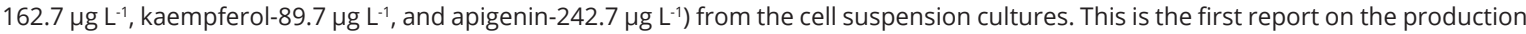
of polyphenols from the cell suspension culture of date palm. This study facilitates further development of large-scale production of polyphenols and the utilization of bioreactors.
\end{abstract}

Index terms: Biomass; growth curve; packed cell volume.

\section{RESUMO}

A tamareira acumula ampla variedade de metabolitos secundários com alto valor nutricional e terapêutico. No presente estudo, calos de tamareira (Phoenix dactylifera L., cv. Shaishi) induzidos a partir de ápices caulinares foram utilizados para estabelecer culturas de suspensão celular em meio líquido Murashige e Skoog (MS) contendo $1,5 \mathrm{mg} \mathrm{L}^{-1}$ de 2-isopenteniladenina (2iP) e $10 \mathrm{mg} \mathrm{L}^{-1}$ de ácido naftaleno acético (ANA). Para estudar a cinética de crescimento, as culturas foram mantidas por 12 semanas e medições semanais foram realizadas para determinar a acumulação de biomassa com base no volume de células empacotadas, peso fresco e peso seco. Além disso, a determinação dos polifenóis (catequina, ácido cafeico, kaempferol e apigenina) foi realizada semanalmente usando cromatografia líquida de alta performance (HPLC). A cultura de 11 semanas foi encontrada mais alta na produção de biomassa $\left(62,9 \mathrm{~g} \mathrm{~L}^{-1}\right.$ de peso fresco e 7,6 $\mathrm{g} \mathrm{L}^{-1} \mathrm{de}$ peso seco) e polifenóis (155,9 $\mu \mathrm{g} \mathrm{L^{-1 }}$ de catequina, $162,7 \mu \mathrm{g} \mathrm{L^{-1 }}$ de ácido cafeico, $89,7 \mu \mathrm{g} \mathrm{L} \mathrm{L}^{-1}$ de kaempferol e $242,7 \mu \mathrm{g} \mathrm{\textrm {L } ^ { - 1 }}$ de apigenina) das culturas de suspensão celular. Este é o primeiro relato sobre a produção de polifenóis em suspensão celular de tamareira. Este estudo facilita a produção em larga escala de polifenóis e o uso de biorreatores.

Termos para indexação: Biomassa; curva de crescimento; volume de células empacotadas.

\section{INTRODUCTION}

Plant secondary metabolites (PSM) are a diverse group of organic compounds that are produced by plants. Nearly 100,000 such compounds have been isolated from higher plants (Verpoorte et al., 1999; Afendi et al., 2012). PSM possess diverse biological activities and applications in the field of pharmaceuticals, insecticides, dyes, flavors, and fragrance industries (Gandhi; Mahajan; Bedi, 2015; Grzegorczyk-Karolak; Kuz'ma; Wysokin'ska, 2016). Although secondary metabolism offers attractive targets for plant breeding, the enormous biosynthetic potential of plant cells remains unexploited (Gandhi; Mahajan; Bedi, 2015).
Date palm, Phoenix dactylifera $\mathrm{L}$., a monocotyledonous angiosperm diploid species $(2 \mathrm{n}=36)$ belongs to the Arecaceae (Palmae) family (Al-Khayri; Jain; Johnson, 2015). It is the oldest and most economically-important fruit tree species in the hot arid regions of the world (Johnson; Al-Khayri; Jain, 2013). Dates represent a high-energy source besides being rich in dietary fibers (Biglari; Al Karkhi; Easa, 2008; El Hadrami; Al-Khayri, 2012). In addition to the macromolecules and other essential micronutrients, phytochemicals like flavonoids, carotenoids, phenolic acids, sterols, procyanidins, and anthocyanins are present in date fruits (Al-Harthi et al., 2015; Farag et al., 2016; Cagno et 
al., 2017; Kamal-Eldin; Ghnimi, 2018). Phenolics account for most of the antioxidant properties of dates (Louaileche; Hammiche; Hamoudi, 2015; Al-Khayri et al., 2018). Polyphenols such as catechin, caffeic acid, kaempferol, and apigenin are present in date fruits (El Hadrami; Daayf; El Hadrami, 2011; Hamad et al., 2015). These polyphenols are the best-known antioxidants used to treat cancer, diabetics, cardiovascular and neurodegenerative diseases (Zaveri, 2006; Shukla; Gupta, 2010; Calderon-Montaño et al., 2011; Rajendra et al., 2011; Kim; Choi, 2013).

Plant cell suspension cultures have been demonstrated to be the best prolific source of somatic embryos in date palm (Al-Khayri, 2001; Zouine; El Hadrami, 2007; Othmani et al., 2009; Al-Khayri; Naik, 2017). Moreover, plant cell suspension cultures have been utilized as an alternative source for the production of high-value bioactive compounds in some plant species (Siva et al., 2012; Satdive et al., 2015). Variation in the growth condition influences the primary and secondary metabolism of plants, and these conditions induce many changes in the external and internal features of the dates (Hamad et al., 2015; Naik; Al-Khayri, 2016). However, limited research has been carried out on the production of bioactive compounds from date palm in vitro cultures. Recently, there has been interest in the in vitro production of secondary metabolites from date palm cell suspension cultures. Taha et al. (2010) enhanced production of phenolic and peroxide compounds in lyophilized cell suspension cultures, obtained from shoot tip and the primordial leaf derived callus cultures of Egyptian date palm cultivars. Furthermore, Taha, Bekheet and El-Bahr (2012) studied the cell growth parameters, phenolic and peroxidase compounds production using a bioreactor. So far, no work has been done on the determination of specific polyphenols from date palm cell culture. Hence, the present investigation was undertaken to evaluate the date palm cell growth curve in relation to optimum production of biomass and specific polyphenol compounds (catechin, caffeic acid, kaempferol, and apigenin).

\section{MATERIAL AND METHODS}

\section{Plant material and explant preparation}

Explant preparation and callus induction were carried out following previously published reports (AlKhayri, 2010; 2012). Shaishi, a commercial cultivar readily available in the Al-Hassa region, was used in this study. The 3-4-year-old offshoots were removed from mother trees and the outer leaves removed, exposing the shoot tip regions which were excised and immediately placed in a chilled antioxidant solution (ascorbic acid and citric acid, $150 \mathrm{mg}$ $\mathrm{L}^{-1}$ each), to prevent oxidation-induced browning. The shoot tip region, about $8 \mathrm{~cm}$ long, was surface sterilized in $70 \%$ ethanol for $1 \mathrm{~min}$ followed by $15 \mathrm{~min}$ in $1.6 \%$ (w/v) sodium hypochlorite solution (30\% v/v Clorox, commercial bleach) containing 3 drops of Tween-20 per $100 \mathrm{~mL}$ solution. After 3 rinses in sterilized distilled water, the tissue surrounding the shoot tip was removed until the shoot tip terminal was exposed. The shoot tips, size $1.5 \mathrm{~cm}^{3}$, were excised and sectioned longitudinally into $6-8$ sections and used as explants for culture initiation.

\section{Culture initiation and callus induction}

Shoot-tip explants were inoculated on the culture initiation medium-modified Murashige and Skoog (MS, 1962) salts supplemented with (per L) $170 \mathrm{mg} \mathrm{NaH} \mathrm{PO}_{4}$, $125 \mathrm{mg}$ myo-inositol, $200 \mathrm{mg}$ glutamine, $1 \mathrm{mg}$ nicotinic acid, $1 \mathrm{mg}$ pyridoxine- $\mathrm{HCl}, 5 \mathrm{mg}$ thiamine, $30 \mathrm{~g}$ sucrose. In addition, the culture medium was supplemented with hormones, agar and activated charcoal according to the culture stages (Table 1). The $\mathrm{pH}$ was adjusted to 5.8 with $1 \mathrm{~N} \mathrm{NaOH}$ and $1 \mathrm{~N} \mathrm{HCl}$, dispensed in $175 \mathrm{~mL}$-culture jars (20 mL per vessel), covered with polyethylene caps and autoclaved at $121{ }^{\circ} \mathrm{C}$ and $1.1 \mathrm{~kg} \mathrm{~cm}^{-2}$ for $15 \mathrm{~min}$. After 12 weeks, the resultant callus was isolated from the explant and transferred to callus proliferation medium (Table 1). After an additional 12 weeks on the proliferation medium, friable callus was separated and cultured on callus maintenance medium (Table 1). All cultures were incubated in darkness at $25 \pm 2{ }^{\circ} \mathrm{C}$ for 12 weeks during which they were subcultured to a fresh medium at 4-weeks intervals. These callus maintenance cultures served as the callus source for establishing cell suspension cultures.

\section{Cell suspension culture}

Cell suspension cultures were initiated by inoculating $0.5 \mathrm{~g}$ scalpel-macerated callus in $50 \mathrm{~mL}$ liquid medium per 250-mL flask containing 50,000 cells $\mathrm{mL}^{-1}$ (Al-Khayri, 2012) and capped with double layers of aluminum foil. The medium consisted of modified MS salts- similar to culture initiation medium. Hormones were added to the medium as indicated in Table 1, pH was adjusted to 5.8 and autoclaved. The cell suspension cultures were incubated on a rotary shaker set at $150 \mathrm{rpm}$ under a $16 \mathrm{~h}$ photoperiod of coolwhite fluorescent light $\left(40 \mu \mathrm{mol} \mathrm{m} \mathrm{m}^{-2} \mathrm{~s}^{-1}\right)$ and $25 \pm 2{ }^{\circ} \mathrm{C}$. After every 2 -weeks interval, cell cultures were measured equally and transferred into two flasks. To these cell suspension cultures fresh medium was added and brought to a final volume of $50 \mathrm{~mL}$. 
Table 1: Consecutive culture stages and their corresponding hormonal, agar and activated charcoal additives supplemented to modified MS medium used for date palm in vitro culture stages.

\begin{tabular}{cccccc}
\hline \multirow{2}{*}{ Culture stage } & \multicolumn{5}{c}{ Hormones, agar and activated charcoal additives } \\
\cline { 2 - 6 } & $2,4-\mathrm{D}\left(\mathrm{mg} \mathrm{L}^{-1}\right)$ & 2ip $\left(\mathrm{mg} \mathrm{L}^{-1}\right)$ & $\mathrm{NAA}\left(\mathrm{mg} \mathrm{L}^{-1}\right)$ & Agar $\left(\mathrm{g} \mathrm{L}^{-1}\right)$ & Activated charcoal $\left(\mathrm{g} \mathrm{L}^{-1}\right)$ \\
\hline Culture initiation & 100 & 3 & - & 8 & 1.5 \\
Callus proliferation & - & 30 & 10 & 8 & 1.5 \\
Callus maintenance & - & 1.5 & 10 & 8 & - \\
Cell suspension & - & 1.5 & 10 & - & - \\
\hline
\end{tabular}

2,4-D: 2,4-dichlorophenoxyacetic acid; 2-iP: 2-isopentenyladenine; NAA: 1-Naphthaleneacetic acid.

\section{Cell line selection}

Two cell lines were selected from the established cell suspension cultures based on the rate of cell proliferation by visual screening. Both cell lines were maintained by continuous subculturing every 4 weeks. At the end of 12 weeks the cell cultures were filtered through Whatman No.1 filter paper (150 mm, England) fitted to a Buchner funnel ( $80 \mathrm{~mm}$, Italy) with the help of a vacuum pump and the cells were oven-dried at $60{ }^{\circ} \mathrm{C}$ for $24 \mathrm{~h}$. Dried tissue samples were ground to fine powder by using a pestle and mortar, stored in a vial $\left(4^{\circ} \mathrm{C}, 1 \mathrm{month}\right)$ and subsequently analyzed for their polyphenol contents.

\section{Kinetics of cell growth}

Kinetics of cell growth in the cell suspension cultures were studied from one of the cell lines producing optimum polyphenol content. The cells, weighing $0.5 \mathrm{~g}$ were cultured to $250-\mathrm{mL}$ flasks containing $50 \mathrm{~mL}$ of cell suspension medium. Culture conditions were the same as described in the cell suspension culture stage.

Packed cell volume (PCV; \%) method was used to monitor the cell growth. To determine the PCV, $10 \mathrm{~mL}$ of cell suspension was placed in a sterile graduated centrifuge tube $(15 \mathrm{~mL})$ and centrifuged at $6000 \mathrm{rpm}$ for $5 \mathrm{~min}$. The packed cell volume recorded as percentage cell mass of the total centrifuged volume. The PCV were recorded at weekly intervals up to 12 weeks and their values plotted in relation to time, and growth curve reflecting various phases of cell growth.

To determine the fresh weight $(\mathrm{g})$, the cell suspension cultures were filtered, using the procedure mentioned in the cell line selection. For dry weight, the cells were oven dried at $60^{\circ} \mathrm{C}$ for $24 \mathrm{~h}$ and the dry weight recorded. These dried tissue samples were ground to fine powder by using a pestle and mortar, stored in a vial $\left(4^{\circ} \mathrm{C}\right.$, 1 month) and subsequently analyzed for their metabolite contents.

\section{Extraction and determination of polyphenols}

Extraction was carried out using $100 \mathrm{mg}$ powdered cell suspension samples in a $15-\mathrm{mL}$ centrifuge tube as described by Naik and Al-Khayri (2017) with some modifications. An amount of $10 \mathrm{~mL}$ of $80 \%$ methanol was added and incubated at $60{ }^{\circ} \mathrm{C}$ under a water bath for $2 \mathrm{~h}$ with intermittent shaking. The extract was centrifuged at $6000 \mathrm{rpm}$ for $20 \mathrm{~min}$. The supernatant sample was filtered through $0.45 \mu \mathrm{m}$ polyvinylidene fluoride (PVDF) membrane filter (Merck Millipore, Ireland) and collected in a $125-\mathrm{mL}$ round-bottom flask. This filtrate was dried at $50{ }^{\circ} \mathrm{C}$ with the rotation speed $250 \mathrm{rpm}$ under reduced pressure in a rotary evaporator (OSB-2100 Eyela, Japan). The dried extracts were dissolved in $1 \mathrm{~mL}$ of $80 \%$ methanol. Dissolved samples were filtered through a 0.45 $\mu \mathrm{m}$ PVDF membrane filter (Merck Millipore, Ireland). The filtrates were collected in $2 \mathrm{~mL}$ high performance liquid chromatography (HPLC) sample vials and used for polyphenol analysis using HPLC system.

Chromatographic analysis of polyphenols was carried out by the HPLC system (Shimadzu Prominence Liquid chromatography, Japan), equipped with $20 \mathrm{AT}$ pump, CTO-20A column oven, SPD-20A UV visible absorbance detector, auto injector 20AT, with CMB-20A data module. The HPLC column Zorbax SB C18 (5 $\mu \mathrm{m}$, $4.6 \mathrm{~mm} \times 150 \mathrm{~mm}$ ), at a column temperature of $25^{\circ} \mathrm{C}$ was used. The mobile phases were $0.5 \%$ acetic acid in Millipore water (solvent A), methanol (solvent B) and acetonitrile (solvent $\mathrm{C}$ ). This mobile phase was filtered through a 0.45 $\mu \mathrm{m}$ PVDF membrane filter (Merck Millipore, Ireland.), then deaerated ultrasonically $\left(25^{\circ} \mathrm{C}, 30 \mathrm{~min}\right.$, Daihan Labtech, Korea) prior to use. The run time was $19 \mathrm{~min}$ at $1 \mathrm{~mL} \mathrm{m^{-1 }}$ flow rate and $25 \mu \mathrm{L}$ injection volume. The gradient of HPLC solvents was as follows: 0-4 min, 80$70 \%$ A:10-20\% B:10\% C; 4-19 min, 70-45\% A:20-40\% B: $10-15 \% \mathrm{C}$. The detection wavelength was set at $280 \mathrm{~nm}$ for $0-10 \mathrm{~min}$ and $272 \mathrm{~nm}$ for $10-19 \mathrm{~min}$. The standards: 
catechin, caffeic acid, and kaempferol except apigenin (Sigma-Aldrich, USA) were dissolved in methanol; apigenin was dissolved in solution containing 1:1 methanol and acetonitrile, then all the standards were diluted with the mobile phase before injecting in HPLC system. The concentration ranges of $1,2,5,10,30$, and $40 \mu \mathrm{g} \mathrm{mL}^{-1}$ were used to develop a calibration curve. Solutions of pure know compounds catechin, caffeic acid, kaempferol, and apigenin were chromatographed as external standards. The polyphenols in cell suspension extracts were identified by comparing their retention times with those of pure standards. Based on the calibration curves of the individual standards the quantitative data of the sample extracts were calculated. The results were expressed as $\mu \mathrm{g} \mathrm{g}^{-1}$ of each polyphenol.

\section{Statistical analysis}

The experiments were performed in triplicate. Results were analyzed by SPSS (IBM SPSS, Statistics Version 21) statistical software package. The analysis of variance (ANOVA) was determined and the mean values were compared according to Duncan's multiple range tests at $P \leq 0.05$ levels.

\section{RESULTS AND DISCUSSION}

\section{Establishment of callus and suspension culture}

Shoot-tip (Figure 1a) explants showed enlargement in the culture initiation medium within 4 weeks of culture (Figure 1b), the enlargement continued up to 12 weeks of culture. The callus cultures turned creamy yellow in callus proliferation medium (Figure 1c) within 4 weeks. After completing 12 weeks of culture the friable creamy callus maintained in the callus maintaining medium (Figure 1d). Taha et al. (2010) and Taha, Bekheet and El-Bahr (2012) reported the similar type of callus formation from the shoot tip explant. In the MS liquid medium (Figure 1e) cells grew and multiplied faster. The establishment of date palm cell suspension cultures is an ideal tool for the efficient production of polyphenols. Our results of callus induction and suspension cultures were corroborated with the findings of Al-Khayri (2012).

\section{Cell line selection}

Initiation of cell cultures begins with the choice of a parent plant with high content of the desired product for callus induction to obtain high-yielding cell lines.

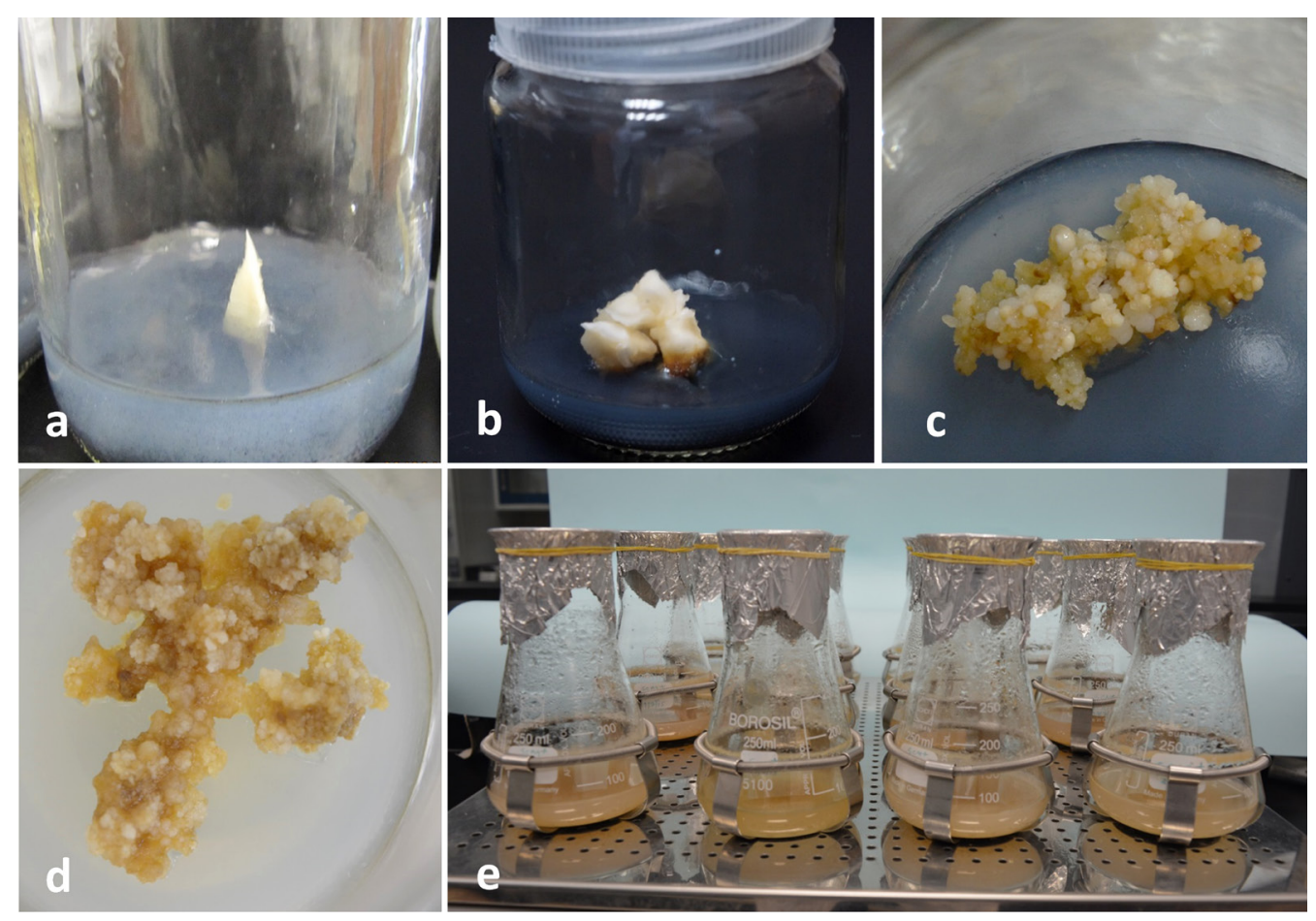

Figure 1: Stages of date palm cv. Shaishi cell suspension culture. a Shoot tip explants on culture initiation medium; b Expansion of explant after 4-wk; c Callus formation in the proliferation medium; d Callus in the maintaining medium; e Cell suspension culture. 
Results revealed that cell line 2 was superior to cell line 1 (Table 2) when compared to all the polyphenols quantified (catechin-7.5 $\mu \mathrm{g} \mathrm{g}^{-1} \mathrm{DW}$, caffeic acid-36.7 $\mu \mathrm{g} \mathrm{g}^{-1} \mathrm{DW}$, kaempferol-1.4 $\mu \mathrm{g} \mathrm{g}^{-1} \mathrm{DW}$, and apigenin-7.2 $\mu \mathrm{g} \mathrm{g}^{-1} \mathrm{DW}$ ). These results have pragmatic inferences for cell suspension culture aimed at increasing the levels of polyphenols in date cultivars. Secondary metabolite accumulation is genotypic dependent in plants which leads to variation in the metabolites accumulation among cultivars (Murthy et al., 2014; Hamad et al., 2015).

Table 2: Polyphenols content in the two cell lines of date palm cell suspension culture.

\begin{tabular}{ccccc}
\hline $\begin{array}{c}\text { Cell } \\
\text { lines }\end{array}$ & $\begin{array}{c}\text { Catechin } \\
\mu \mathrm{g} \mathrm{g}^{-1} \mathrm{DW}\end{array}$ & $\begin{array}{c}\text { Caffeic acid } \\
\mu \mathrm{g} \mathrm{g}{ }^{-1} \mathrm{DW}\end{array}$ & $\begin{array}{c}\text { Kaempferol } \\
\mu \mathrm{g} \mathrm{g}^{-1} \mathrm{DW}\end{array}$ & $\begin{array}{c}\text { Apigenin } \\
\mu \mathrm{g} \mathrm{g}^{-1} \mathrm{DW}\end{array}$ \\
\hline 1 & $5.3 \pm 1.9$ & $23.9 \pm 3.0$ & $1.1 \pm 0.1$ & $1.2 \pm 0.1$ \\
2 & $7.5 \pm 1.5$ & $36.7 \pm 8.2$ & $1.4 \pm 0.0$ & $7.2 \pm 0.6$ \\
\hline
\end{tabular}

Values represent the mean $\pm \mathrm{SE}$.

\section{Kinetics of cell growth}

There are various methods to measure the in vitro cell growth including dry weight, fresh weight, packed cell volume, cell or colony counting (Dixon, 1985; Naik; Murthy, 2010; Al-Khayri, 2012). In the present experiments, date palm cv. Shaishi cell suspension cultures were harvested at different time intervals to measure the PCV. The PCV was significantly affected by culture duration. As the number of weeks increased the percentage of PCV also increased (Figure 2a). The growth curve reflected lag, exponential, stationary and death phases of cell growth. The PCV value was found optimum in 11-week-old cultures $(11 \%)$. The PCV values showed significantly different at weekly intervals and the results were corroborated with an earlier report where the cv. Barhee was used (Al-Khayri et al., 2012). The accumulation of biomass [FW and DW of the cells] from 1-11 weeks of suspension culture showed an increasing pattern and declined at 12 weesk of culture (Figure 2b, c). The optimum value of FW-62.9 g L-1 and DW-7.6 $\mathrm{g} \mathrm{L}^{-1}$ was observed at 11-week-old suspension culture which was the stationary phase of the culture. Researchers reported the maximum FW in the 4-weekold cell suspension culture of Indian ginseng, Withania somnifera, (Praveen; Murthy, 2010) and Niger seed, Guizotia abyssinica, (Naik; Murthy, 2010). This difference is because of the plant nature, date palm is a tree species and needs more days to culture when compared to herbs and shrubs. In the Indian leadwort, Plumbago rosea, embryogenic cell suspension culture the FW and DW also reached their maximum at the stationary phase of growth (Silja; Gisha; Satheeshkumar, 2014). Recently, the similar pattern of growth curve was observed with respect to FW and DW in the common hazel, Corylus avellana, cell suspension cultures (Gallego et al., 2015). In another report the cell suspension culture of babchi, Psoralea corylifolia, grown relatively fast and reached optimum biomass in 15 days as cells reached into early stationary phase (Satdive et al., 2015). In Orostachys cartilaginous cell culture, biomass accumulation reached the maximum in 25 days, thereafter the decline phase started (Piao et al., 2017).
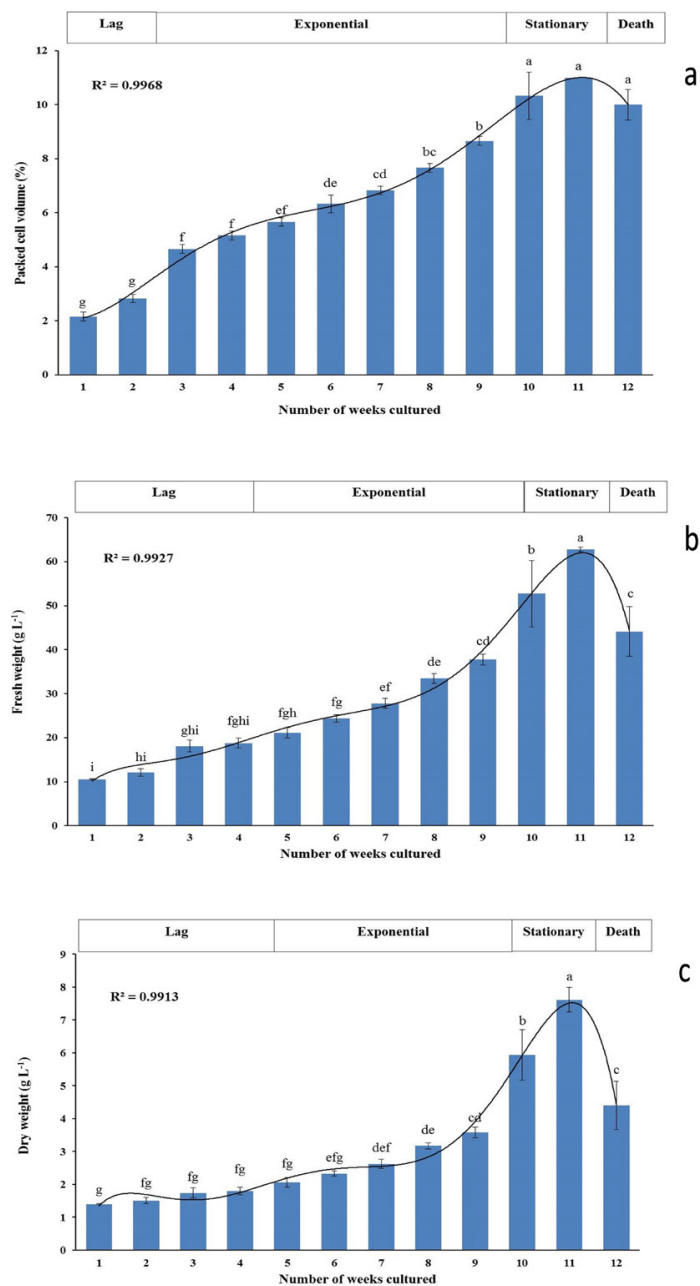

Figure 2: Growth curve of the date palm cv. Shaishi cell suspension culture showing a PCV (\%), b fresh weight, and c dry weight in relation to time. Standard error is represented as bar in the graph. Mean values following the same letter in the graph is not significantly different, according to Duncan's multiple range $(p \leq 0.05)$ test. 


\section{Determination of polyphenols}

The calibration curves of standards (Figure $3 a, b$, c, d) and HPLC chromatogram of standards (Figure 4a) were used to determine the polyphenol content of the cell suspension extract (Figure 4b). Results indicated that polyphenols are accumulating in the cell suspension culture of date palm cv. Shaishi at various quantities with respect to their stages of growth. The highest significant amount of polyphenols was accumulated in 1 week of culture (catechin-151.5 $\mu \mathrm{g} \mathrm{g}^{-1} \mathrm{DW}$, caffeic acid-60.2 $\mu \mathrm{g} \mathrm{g}^{-1} \mathrm{DW}$, kaempferol-29.0 $\mu \mathrm{g} \mathrm{g}^{-1} \mathrm{DW}$, and apigenin-75.9 $\mu \mathrm{g} \mathrm{g}^{-1} \mathrm{DW}$ ), and as the number of weeks increased polyphenol accumulation decreased (Table 3). Reduction in the growth has been directly associated with an increase in the accumulation of phenolic compounds (Taha; Bekheet; El-Bahr, 2012). Time course accumulation of polyphenols was highest in the initial phase of growth, but productivity was much less at these time intervals, when compared to their optimum level of polyphenol production at 11 weeks (stationary phase) of culture. At the exponential phase (3-9 weeks) of culture the production of polyphenols was moderate. At the death phase (12 weeks) of culture the accumulation of polyphenols and their productivity was lower. The productivity of catechin $\left(155.9 \mu \mathrm{g} \mathrm{L}^{-1}\right)$, caffeic acid $\left(162.7 \mu \mathrm{g} \mathrm{L}^{-1}\right)$, kaempferol $\left(89.7 \mu \mathrm{g} \mathrm{L}^{-1}\right)$, and apigenin $\left(242.7 \mu \mathrm{g} \mathrm{L}^{-1}\right)$ from the cell suspension cultures at stationary phase i.e. 11 weeks of cultures was very high when compared to the other stages of culture (Table 3). Praveen and Murthy (2010) in Withania somnifera cell suspension culture reported that withanolide A, accumulation followed the similar trend of the biomass accumulation. In the cell suspension culture of wormwood, Artemisia absinthium, peak values of total phenolics (day 30) and total flavonoids (day 33) were observed in the early stationary phase
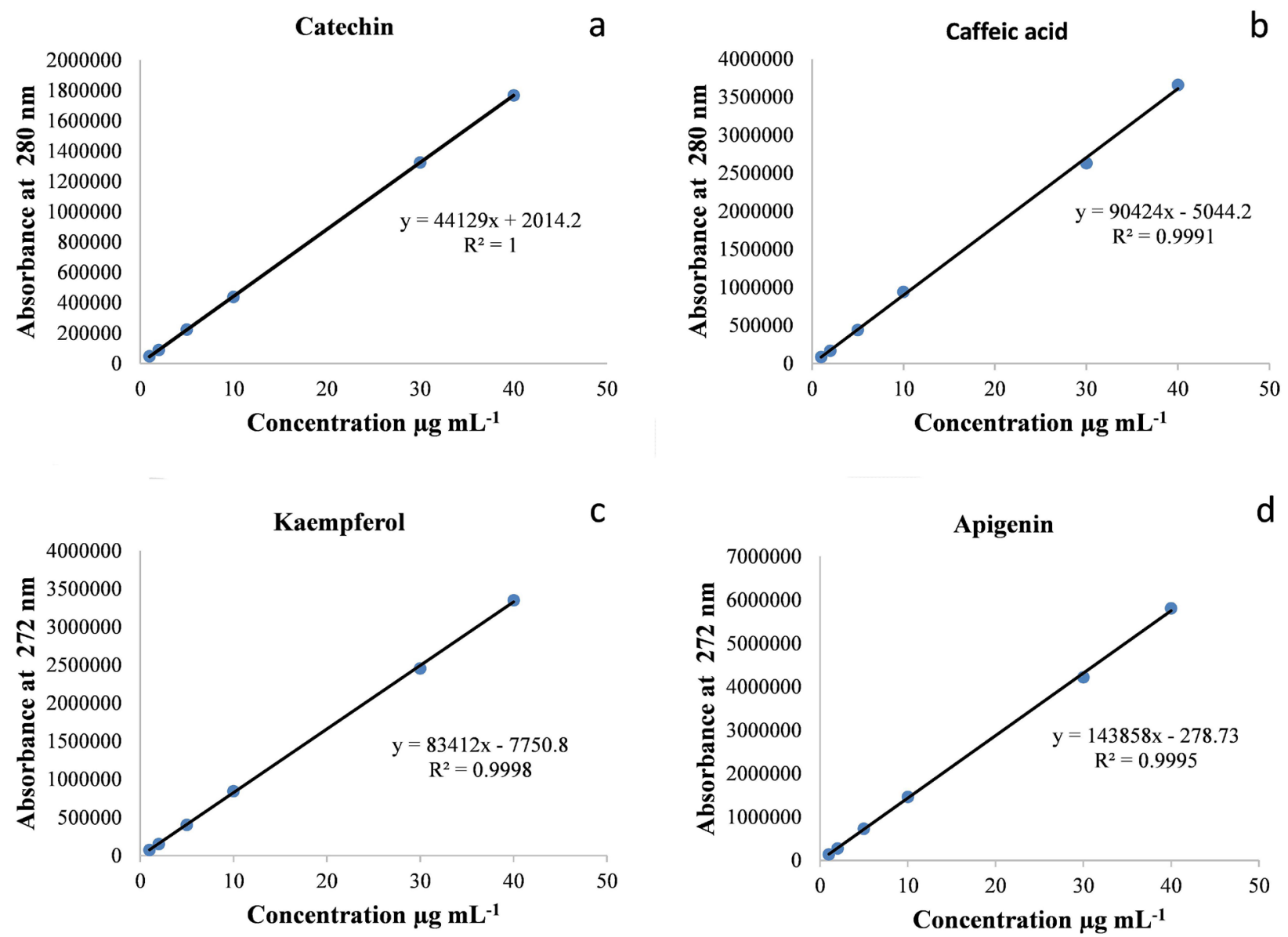

Figure 3: Calibration curve of the HPLC standards. a catechin, b caffeic acid, c kaempferol, d apigenin. 
of the growth curve (Ali; Abbasi; Ihsan-ul-haq, 2013). Karwasara and Dixit (2013) recorded the optimum level of camptothecin production at the onset of stationary phase in the cell suspension culture of ghanera, Nothapodytes nimmoniana. In secondary metabolite production from the cell suspension culture of Corylus avellana reported by Satdive et al. (2015), the phytoestrogen production started on day 5 and the contents increased constantly. When the cultures reached at stationary phase the production of daizein and genistein was optimum, thus indicating that biomass production and secondary metabolites productions are correlated. Zimare, Kakade and Malpathak (2017) also in cow plant, Gymnema sylvestre, cell suspension culture explained the similar pattern of biomass and gymnemic acid accumulation. In our future work various parameters will be tested to optimize the production of biomass and polyphenols in the date cell suspension culture.

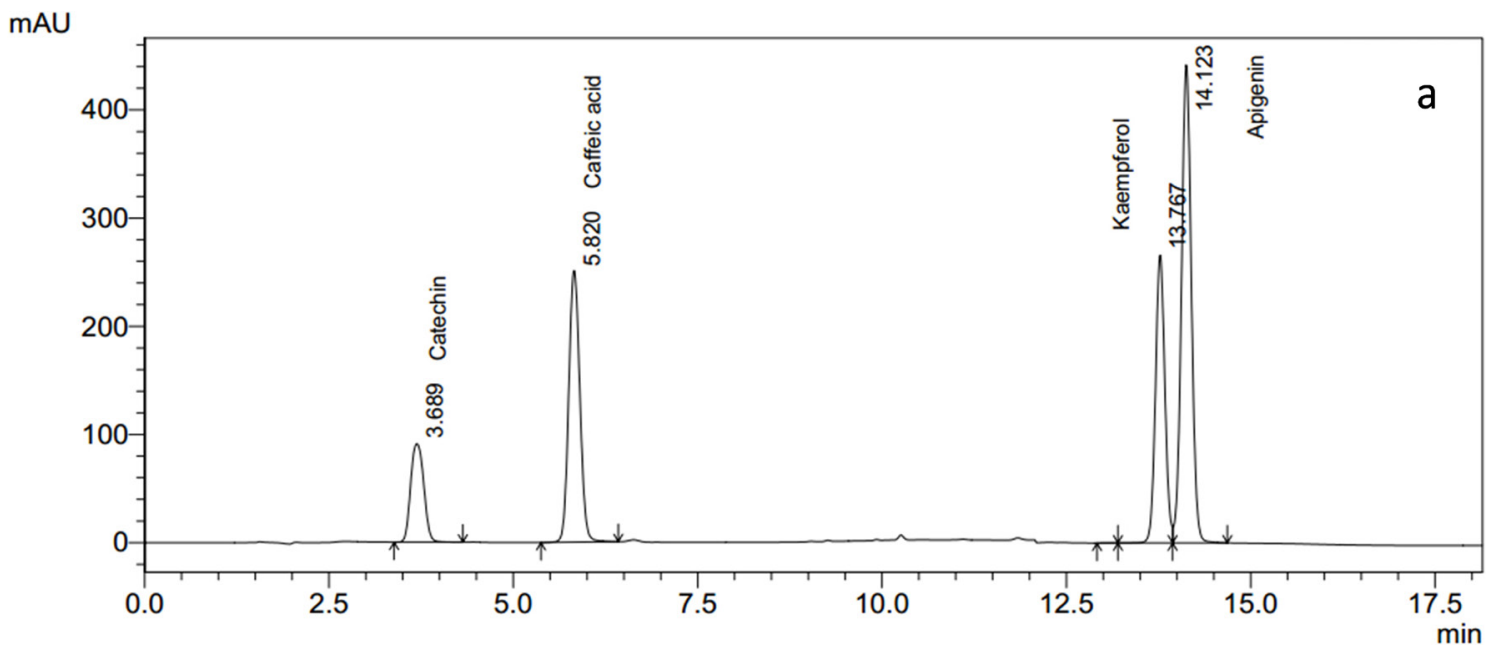

mAU

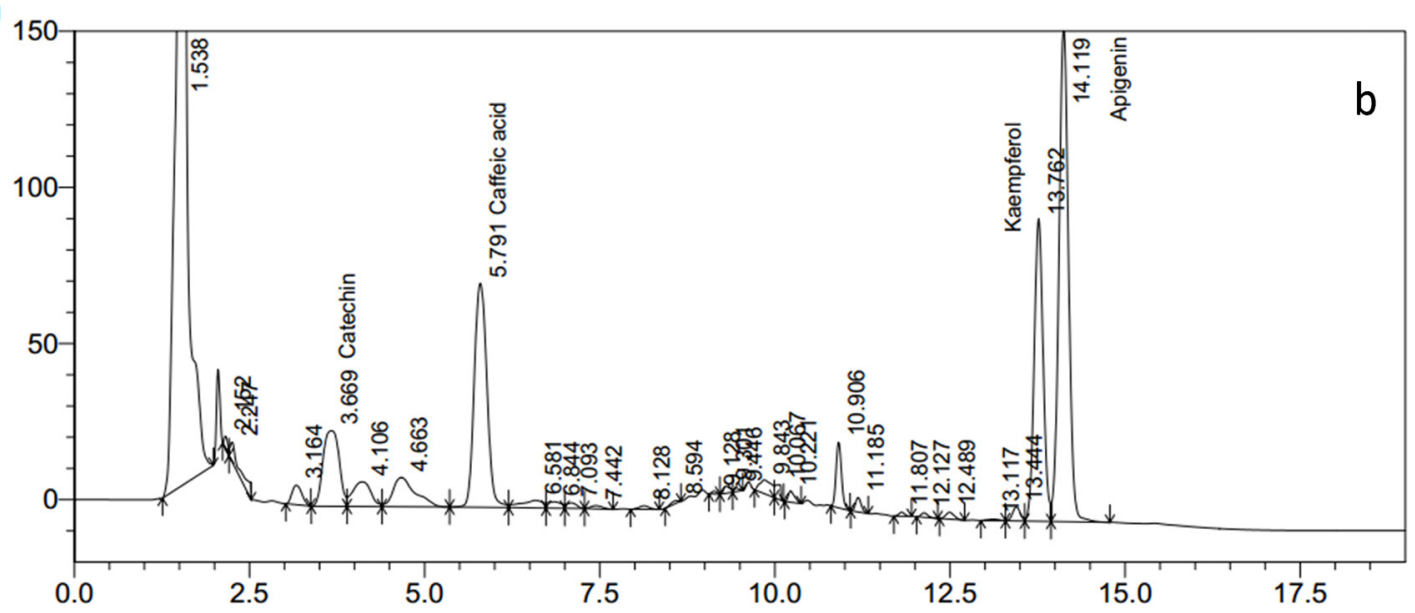

Figure 4: a HPLC chromatogram of standards; b HPLC chromatogram of methanolic extract of date palm cv. Shaishi cell suspension culture. 


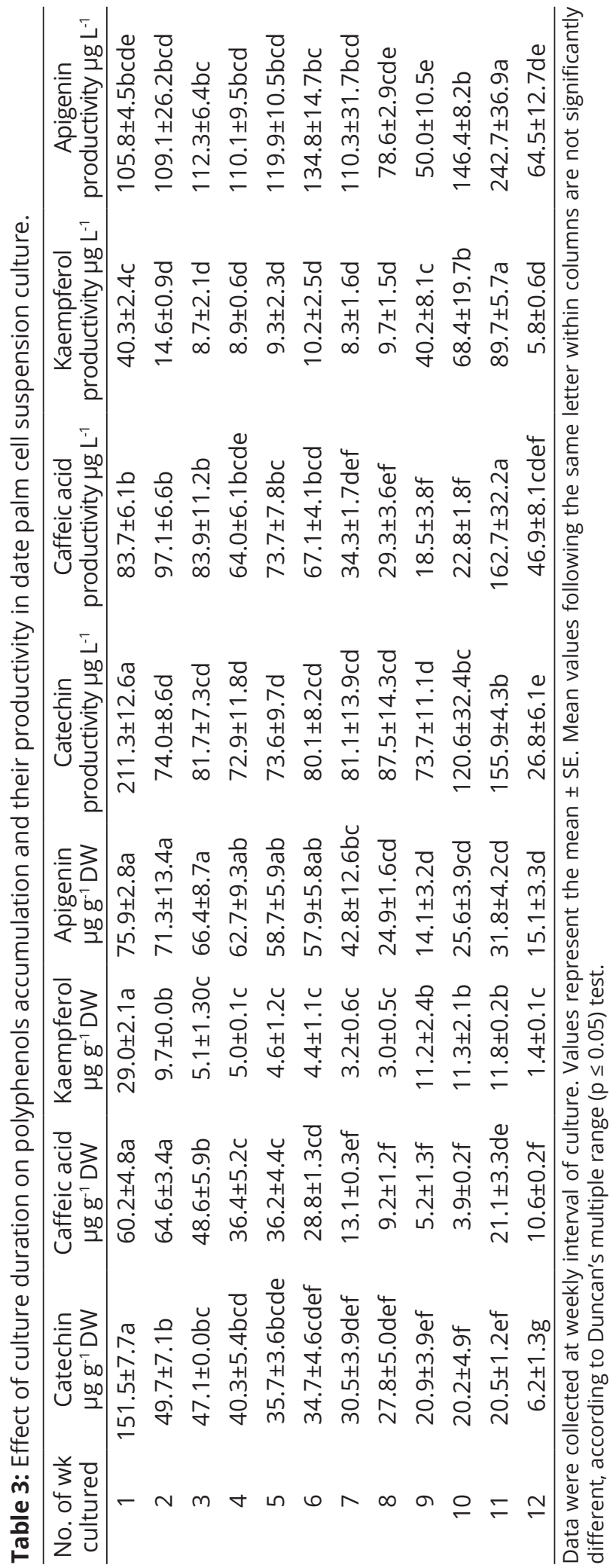

\section{CONCLUSIONS}

In the present study cell suspension cultures of date palm cultivar Shaishi were successfully established by selection of a high yielding cell line. The complete kinetic growth study reflects the 11 weeks culture (stationary phase) was found to be suitable for the optimum biomass production. The optimum content of catechin, caffeic acid, kaempferol, and apigenin from the cell suspension culture were accumulated at the lag phase of culture, but the productivity of the polyphenols was found maximum in the stationary phase. This study is useful to obtain maximum production of polyphenols from the cell suspension culture of date palm. It is suggested further experiments for optimizing the conditions of cell suspension culture media for the successful large-scale production of useful polyphenols from the of date palm and scale-up process.

\section{ACKNOWLEDGMENTS}

The authors are grateful to King Abdulaziz City for Science and Technology (KACST), Saudi Arabia for financial support in the form of research grant (Project No. Arp-34-63).

\section{REFERENCES}

AFENDI, F. M. et al. KNApSAcK family databases: Integrated metabolite-plant species databases for multifaceted plant research. Plant and Cell Physiology, 53(2):e1-12, 2012.

AL-HARTHI, S. S. et al. Quantification of phenolic compounds, evaluation of physicochemical properties and antioxidant activity of four date (Phoenix dactylifera L.) varieties of Oman. Journal of Taibah University Medical Sciences, 10(3):346-352, 2015.

ALI, M.; ABBASI, B. H.; IHSAN-UL-HAQ. Production of commercially important secondary metabolites and antioxidant activity in cell suspension cultures of Artemisia absinthium L. Industrial Crops and Products, 49:400-406, 2013.

AL-KHAYRI, J. M. Determination of the date palm cell suspension growth curve, optimum plating efficiency, and influence of liquid medium on somatic embryogenesis. Emirates Journal of Food and Agriculture, 24(5):444-455, 2012.

AL-KHAYRI, J. M. et al. Advances in date palm (Phoenix dactylifera L.) Breeding. In: AL-KHAYRI, J. M.; JAIN, S. M.; JOHNSON, D. V. Advances in Plant Breeding Strategies: Fruits, Switzerland: Springer International Publishing AG, 2018. p.727-771. 
AL-KHAYRI, J. M. Optimization of biotin and thiamine requirements for somatic embryogenesis of date palm (Phoenix dactylifera L.). In Vitro Cellular \& Developmental Biology-Plant, 37:453-456, 2001.

AL-KHAYRI, J. M. Somatic embryogenesis of date palm (Phoenix dactylifera L.) improved by coconut water. Biotechnology, 9:477-484, 2010.

AL-KHAYRI, J. M.; JAIN, S. M.; JOHNSON, D. V. Date Palm Genetic Resources and Utilization, Vol. 2: Asia and Europe, Dordrecht: Springer, 2015. 566p.

AL-KHAYRI, J. M.; NAIK, P. M. Date palm micropropagation: Advances and applications. Ciência e Agrotecnologia, 41(4):347-358, 2017.

BIGLARI, F.; ALKARKHI, A. F. M.; EASA, A. M. Antioxidant activity and phenolic content of various date palm (Phoenix dactylifera) fruits from Iran. Food Chemistry, 107:1636-1641, 2008.

CAGNO, R. D. et al. Bioprocessing technology to exploit organic palm date (Phoenix dactylifera L. cultivar Siwi) fruit as a functional dietary supplement. Journal of Functional Foods, 31:9-19, 2017.

CALDERON-MONTAÑO, J. M. et al. A review on the dietary flavonoid kaempferol. Mini Reviews in Medicinal Chemistry, 11(4):298-344, 2011.

DIXON, R. A. Isolation and maintenance of callus and cell suspension cultures. In: DIXON, R. A. Plant cell cultures: A practical approach, Oxford: IRL Press, 1985. p.1-20.

EL HADRAMI, A.; AL-KHAYRI, J. M. Socioeconomic and traditional importance of date palm. Emirates Journal of Food and Agriculture, 24:371-385, 2012.

EL HADRAMI, A.; DAAYF, F.; EL HADRAMI, I. Secondary metabolites of date palm. In: JAIN, S. M.; AL-KHAYRI, J. M.; JOHNSON, D. V. Date palm biotechnology, Dordrecht: Springer, 2011. p.653-674.

FARAG, M. A. et al. Metabolite profiling in 18 Saudi date palm fruit cultivars and their antioxidant potential via UPLC-qTOF-MS and multivariate data analyses. Food and Function, 7:1077-1086, 2016.

GALLEGO, A. Assessing factors that affect the growth of Corylus avellana cell suspension cultures: A statistical approach. In Vitro Cellular \& Developmental Biology-Plant, 51:530538, 2015.

GANDHI, S. G.; MAHAJAN, V.; BEDI, Y. S. Changing trends in biotechnology of secondary metabolism in medicinal and aromatic plants. Planta, 241:303-317, 2015.
GRZEGORCZYK-KAROLAK, I.; KUZ'MA, Ł.; WYSOKIN'SKA, $\mathrm{H}$. In vitro cultures of Scutellaria alpina as a source of pharmacologically active metabolites. Acta Physiologiae Plantarum, 38(1):1-9, 2016.

HAMAD, I. et al. Metabolic analysis of various date palm fruit (Phoenix dactylifera L.) cultivars from Saudi Arabia to assess their nutritional quality. Molecules, 20:13620-13641, 2015.

JOHNSON, D. V.; AL-KHAYRI, J. M.; JAIN, S. M. Seedling date palms (Phoenix dactylifera L.) as genetic resources. Emirates Journal of Food and Agriculture, 25(11):809-830, 2013.

KAMALELDIN, A.; GHNIMI, S. Classification of date fruit (Phoenix dactylifera, L.) based on chemometric analysis with multivariate approach. Journal of Food Measurement and Characterization, 12(2):1020-1027, 2018.

KARWASARA, V. S.; DIXIT, V. K. Culture medium optimization for camptothecin production in cell suspension cultures of Nothapodytes nimmoniana (J. Grah.) Mabberley. Plant Biotechnology Report, 7:357-369, 2013.

KIM, S. H.; CHOI, K. C. Anti-cancer effect and underlying mechanism(s) of kaempferol, a phytoestrogen, on the regulation of apoptosis in diverse cancer cell models. Toxicology Research, 29(4):229-234, 2013.

LOUAILECHE, H.; HAMMICHE, D.; HAMOUDI, F. Total phenolic, flavonoid contents and in vitro antioxidant activity of Algerian date palm varieties: A comparative study. American Journal of Food Science and Health, 1(3):63-68, 2015.

MURASHIGE, T.; SKOOG, F. A revised medium for rapid growth and bioassays with tobacco tissue cultures. Physiologia Plantarum, 15:473-497, 1962.

MURTHY, H. N. et al. Strategies for enhanced production of plant secondary metabolites from cell and organ cultures. In: PAEK, K. Y.; MURTHY, H. N.; ZHONG, J. J. Production of biomass and bioactive compounds using bioreactor technology, Dordrecht: Springer, 2014. p.471-508.

NAIK, P. M.; AL-KHAYRI, J. M. Abiotic and biotic elicitors-role in secondary metabolites production through in vitro culture of medicinal plants. In: SHANKER, A. K.; SHANKAR, $C$. Abiotic and biotic stress in plants - recent advances and future perspectives, Croatia: InTech, 2016. p.247-277.

NAIK, P. M.; AL-KHAYRI, J. M. Extraction and estimation of secondary metabolites from date palm cell suspension culture. In: AL-KHAYRI, J. M.; JAIN, S. M.; JOHNSON, D. V. Date palm biotechnology protocols volume 1, Methods in molecular biology, vol. 1637. New York: Humana Press, 2017. p.319-332. 
NAIK, P. M.; MURTHY, H. N. Somatic embryogenesis and plant regeneration from cell suspension culture of niger (Guizotia abyssinica Cass.). Acta Physiologiae Plantarum, 32:75, 2010.

OTHMANI, A. et al. Somatic embryogenesis and plant regeneration in date palm Phoenix dactylifera L., cV. Boufeggous is significantly improved by fine chopping and partial desiccation of embryogenic callus. Plant Cell, Tissue and Organ Culture, 97:71-79, 2009.

PIAO, X. C. et al. Cell suspension culture of Orostachys cartilaginous in bioreactor systems for bioactive compound production and evaluation of their antioxidant properties. Acta Physiologiae Plantarum, 39:70, 2017.

PRAVEEN, N.; MURTHY, H. N. Establishment of cell suspension cultures of Withania somnifera for the production of withanolide A. Bioresource Technology, 101:6735-6739, 2010.

RAJENDRA, P. N. et al. Inhibitory effect of caffeic acid on cancer cell proliferation by oxidative mechanism in human HT1080 fibrosarcoma cell line. Molecular and Cellular Biochemistry, 349(1-2):11-19, 2011.

SATDIVE, R. et al. Aggregate cell suspension cultures of Psoralea corylifolia improved phytoestrogens production. Biotechnology and Bioprocess Engineering, 20:373-379, 2015.

SHUKLA, S.; GUPTA, S. Apigenin: A promising molecule for cancer prevention. Journal of Agricultural and Food Chemistry, 27(6):962-978, 2010.

SILJA, P. K.; GISHA, G. P.; SATHEESHKUMAR, K. Enhanced plumbagin accumulation in embryogenic cell suspension cultures of Plumbago rosea L. following elicitation. Plant Cell, Tissue and Organ Culture, 119:469-477, 2014.

SIVA, R. et al. Anthraquinones dye production using root cultures of Oldenlandia umbellata L. Industrial Crops and Products, 37:415-419, 2012.

TAHA, H. S. et al. Implement of DMSO for enhancement and production of phenolic and peroxides compounds in suspension cultures of Egyptian date palm (Zaghlool and Samany) cultivars. Journal of Biotechnology and Biochemistry, 1:1-10, 2010.

TAHA, H. S.; BEKHEET, S. A.; EL-BAHR, M. K. A new concept for production and scaling up of bioactive compounds from Egyptian date palm (Zaghlool) cultivat using bioreactor. Emirates Journal of Food and Agriculture, 24:425-433, 2012.

VERPOORTE, R. et al. Metabolic engineering of plant secondary metabolite pathways for the production of fine chemicals. Biotechnology Letters, 21:467-479, 1999.

ZAVERI, N. T. Green tea and its polyphenolic catechins: Medicinal uses in cancer and noncancer applications. Life Sciences, 78:2073-2080, 2006.

ZOUINE, J.; EL HADRAMI, I. Effect of 2,4-D, glutamine and BAP on embryogenic suspension culture of date palm (Phoenix dactylifera L.). Scientia Horticulturae, 112:221-226, 2007.

ZIMARE, S. B.; KAKADE, P. S.; MALPATHAK, N. P. Unorganized (cell suspension) cultures: A biotechnological tool for enhancement of biomass and gymnemic acid in Gymnema sylvestre. Plant Cell Biotechnology and Molecular Biology, 18(5-6):281-289, 2017. 